NBER WORKING PAPER SERIES

\title{
IS THE MEDITERRANEAN THE NEW RIO GRANDE? US AND EU IMMIGRATION PRESSURES IN THE LONG RUN
}

\author{
Gordon Hanson \\ Craig McIntosh \\ Working Paper 22622 \\ http://www.nber.org/papers/w22622 \\ NATIONAL BUREAU OF ECONOMIC RESEARCH \\ 1050 Massachusetts Avenue \\ Cambridge, MA 02138 \\ September 2016
}

The views expressed herein are those of the authors and do not necessarily reflect the views of the National Bureau of Economic Research.

NBER working papers are circulated for discussion and comment purposes. They have not been peer-reviewed or been subject to the review by the NBER Board of Directors that accompanies official NBER publications.

(C) 2016 by Gordon Hanson and Craig McIntosh. All rights reserved. Short sections of text, not to exceed two paragraphs, may be quoted without explicit permission provided that full credit, including $(\odot$ notice, is given to the source. 
Is The Mediterranean The New Rio Grande? US And EU Immigration Pressures In The Long Run Gordon Hanson and Craig McIntosh

NBER Working Paper No. 22622

September 2016

JEL No. F22,J61

\begin{abstract}
How will worldwide changes in population affect pressures for international migration in the future? We contrast the past three decades, during which population pressures contributed to substantial labor flows from neighboring countries into the United States and Europe, with the coming three decades, which will see sharp reductions in labor-supply growth in Latin America but not in Africa or much of the Middle East. Using a gravity-style empirical model, we examine the contribution of changes in relative labor-supply to bilateral migration in the 2000s and then apply this model to project future bilateral flows based on long-run UN forecasts of working-age populations in sending and receiving countries. Because the Americas are entering an era of uniformly low population growth, labor flows across the Rio Grande are projected to slow markedly. Europe, in contrast, will face substantial demographically driven migration pressures from across the Mediterranean for decades to come. Although these projected inflows would triple the first-generation immigrant stocks of larger European countries, they would still absorb only a small fraction of the 800-million-person increase in the working-age population of SubSaharan Africa that is projected to occur over the coming 40 years.
\end{abstract}

\author{
Gordon Hanson \\ IR/PS 0519 \\ University of California, San Diego \\ 9500 Gilman Drive \\ La Jolla, CA 92093-0519 \\ and NBER \\ gohanson@ucsd.edu \\ Craig McIntosh \\ IR/PS 0519 \\ University of California, San Diego \\ 9500 Gilman Drive \\ La Jolla, CA 92093-0519 \\ ctmcintosh@ucsd.edu
}


The tens of thousands of migrants streaming into Europe during late 2015 and early 2016 created an indelible image of how humanitarian crises - in this case associated with the Syrian civil war-propel international migration. Although political instability in the Levant may have kicked migration to Europe into a higher gear, immigration flows to the continent in the medium- and long-run are likely to be sustained by sharp differentials in labor-supply growth between regions to the north and to the south of the Mediterranean Sea. The present European migration scene is the latest act in a long-running global drama in which cross-country differences in population growth, abetted by disparities in aggregate labor productivity, create pressures for international migration. Periodically, economic or political crises unleash these pressures and generate sustained flows.

During the last quarter of the $20^{\text {th }}$ century, the principal actors in this global drama were Mexico and the United States. The US baby boom came to an abrupt halt in the early 1960s, causing growth in native-born labor supply to slow sharply two decades hence- once the babyboom generation had fully reached working age. In Mexico, birth rates declined much later. High fertility in the 1960s - when Mexico's fertility rate (the number of births per woman of childbearing age) averaged 6.8 versus 3.0 in the United States-meant that Mexico's labor force was expanding rapidly in the early 1980s, just as a severe financial crisis hit. This crisis, and the decade and a half of economic instability that ensued, unleashed a great wave of Mexican migration to the US (Hanson and McIntosh 2010). Encouraging this flow was steady US economic growth during the "Great Moderation" period from the mid-1980s up through 2007 (Bernanke 2004). In a pattern common to migration events stretching back into human history, early migrants eased the transition for later arrivals by offering advice on how to find jobs and housing, opening familiar stores and restaurants, and creating enclaves in which Spanish was spoken alongside English (Massey, Durand, Alarcon, and Gonzalez 1987; Munshi 2003).

The Mexican migration wave to the United States has now crested. Fertility rates in Mexico, at 2.3, are only modestly above those in the United States, at 1.9 (World Development Indicators, data for 2013). Labor-supply growth in the two countries is projected to be roughly the same in coming decades. Although living standards in Mexico remain well below US levels, Mexico has tamed the macroeconomic volatility it experienced during the 1980s and 1990s. Net US immigration from Mexico plunged after the onset of the Great Recession in 2007 and has been slightly negative every year since (Villarreal, 2014; Gonzalez Barrera, Lopez, and Rohal 2015). Absent a significant new economic or political crisis in Mexico, or unexpectedly robust US economic growth, it is unlikely that Mexico-to-US migration rates will again reach the levels witnessed between the early 1980s and the mid-2000s.

The European immigration context today looks much like the United States did three decades ago. In Europe, which long ago made its demographic transition to low birth rates, 
declines in fertility in the 1970s and 1980s set the stage for a situation in which the number of working-age residents is in absolute decline (as discussed in this journal by Lee 2003). Countries in the North Africa and Middle East region, in contrast, have had continued high fertility, creating bulging populations of young people looking for gainful employment in labor markets plagued by low wages and the scarcity of steady work. Further to the south, population growth rates in Sub-Saharan Africa, a region with still lower relative earnings, remain among the highest in the world.

Many countries in North Africa and the Middle East are in a period of profound political and economic upheaval. Migrants escaping military conflict in Afghanistan, Iraq, Libya, and Syria are crossing the Straits of Gibraltar, the land and sea borders that divide Turkey and Greece, and the narrow Mediterranean passage that separates northern Libya and southern Italy. Further to the south, conflicts in Chad, Eritrea, Mali, and Nigeria are also generating labor outflows. These new triggers are being tripped in a demographic environment that is ideal for perpetuating emigration well into the future. As further motivation, established populations of Algerians in France, Moroccans in Spain, the Turkish in Germany, and Sub-Saharan Africans in Italy may offer support and solace to the new arrivals as they settle in.

In this paper, we assess the contribution of differentials in population growth to international migration in the long run. We look backward to the significant migration episodes of the last 30 years and forward to the pressures that will encourage flows in coming decades. Whereas in the 1970s the world was neatly divided between a high-income and low-populationgrowth North and a low-income and high-population-growth South, by the 2040s the only high-population-growth countries likely to remain will be in Sub-Saharan Africa and parts of the Middle East. We use past population growth to estimate a gravity model of bilateral migration and then apply the estimated coefficients to project future migration out to midcentury, as implied by population forecasts. This exercise projects the stock of first-generation immigrants to remain flat in the United States, as a consequence of the cessation of Mexico's emigration surge, and to nearly triple in the United Kingdom, Spain, and Italy.

Our exercise is not intended as a hard prediction of the future, but as a guide for how demographic trends will recalibrate pressures for international labor movements. If Europe tightens its borders significantly, the United States decides to relax entry restrictions, or the nations of East Asia change course to allow labor inflows at much higher levels than in the past, global migration may evolve in a very different manner from what our analysis suggests. Future migration will undoubtedly be shaped also by crises that we cannot foresee, much as the Arab Spring and the subsequent tumult around the Mediterranean caught the European Union by surprise, leaving it ill-equipped for mass arrivals of refugees on its shores. Yet there remains a certain destiny in global demography. Just as population growth in most of Latin America is cascading downward and looks set to drop below replacement levels within a couple of decades, it is proceeding apace in Sub-Saharan Africa and much of North Africa and the Middle 
East. These patterns mean that in the future the United States and Europe are likely to occupy migration neighborhoods that differ immensely from those of the past.

\section{Global Migration Patterns}

In 1970, there was little indication either in the United States or in Europe that immigration would become a major political issue by century's end. The share of the US population that was foreign-born in 1970 was at a 100-year low, at 4.7 percent. Concerns in western Europe centered not so much on excess entry as on restrictions that impeded those living behind the Iron Curtain from moving west (Joppke 1999). At the time, policymakers in Bonn, Paris, and London wanted, if anything, to facilitate immigration, not to block it. Today, of course, anxiety about the arrival of foreign workers is running high.

We begin our discussion by summarizing the present contours of immigration in the United States and other OECD nations. We focus on the OECD both because it is a grouping that includes all high-income destination economies, aside from the oil-rich states of the Persian Gulf, and because it provides immigration data by age cohorts that are comparable across countries. We then examine past and projected future population growth worldwide, paying particular attention to forecasted changes in growth rates in current migration hot spots.

\section{Immigrant Presence in OECD Countries}

Perhaps the most fundament concept in the economics of immigration is that international labor flows are driven by differences in income among countries. The seminal work of Sjaastad (1962) framed immigration as an investment decision, in which an individual considers incurring an up-front cost from migrating to another location-due to moving expenses, fees for obtaining a visa, time out of the labor market, and the psychic cost of leaving home-in return for a higher present discounted value of lifetime income. Although the migration decision in theory is based on comparing future income streams at home versus abroad, the vast majority of empirical work uses current income as a summary statistic for cross-country differences in labor-market conditions (for example, Clark, Hatton, and Williamson 2007; Mayda 2008). In our first foray into the data, we follow this convention. Later, we introduce differences in relative labor supply growth as an additional indicator of future income streams.

Figure 1 plots the share of the population that is foreign-born in 2010 against mean PPPadjusted per capita GDP averaged over 2000 to 2010 for OECD countries. Values of per capita GDP are from the Penn World Tables 8.0. The 2010 foreign-born population share summarizes immigrant inflows over preceding decades, while mean income for the 2000s provides a metric 
of economic conditions in destination countries around the time during which the preponderance of migrants would have made their location choices.

Clearly, lower-income countries, such as Bulgaria, Chile, Mexico, and Romania, lure few immigrants, while higher-income economies are attractive destinations. The regression line is strongly positive and statistically significant at the 1 percent level. For every 10 percent increase in average income, the foreign-born population share rises by 0.4 percent. Yet even after controlling for income, there is also enormous heterogeneity in migrant inflows. While Australia and the Netherlands have near identical average per capita GDP, the former's foreignborn share (26.6 percent) is nearly two-and-a-half times that of the latter (11.1 percent). Also dramatic is the contrast between Germany and Japan, two countries that again have similar average living standards. Germany's foreign-born share at 13.0 percent is almost exactly on the regression line. At 1.7 percent, the share of immigrants in Japan's population is the lowest among the higher-income nations of the OECD. Other pairs with common average incomes but sharply differing foreign-born shares include Estonia (15.9 percent) and the Slovak Republic (0.3 percent); Slovenia (11.2 percent) and Korea (2.0 percent); and Belgium (14.9 percent) and Denmark (7.7 percent). International migration is apparently about more than current income differences between countries.

A vast literature examines the factors that shape bilateral migration flows (for a survey, see Hanson 2010). Similar to findings for the "gravity model" of trade (Head and Mayer 2015), migration is strongly decreasing in geographic distance between countries and significantly higher between country pairs that share a land border, a common language, and past colonial linkages (Mayda 2010). These additional factors explain in part why Anglo-phone countries are particularly popular destinations for international migrants. Four of the six highest foreign-born population shares are found in countries that are former British subjects: Australia, Canada, Ireland, and New Zealand. These nations have the appeal of speaking the language that the British Empire made the lingua franca of global commerce. Also, the era of empire helped establish migration networks - and later the creation of preferential immigration schemes such as those among British Commonwealth nations - that resulted in reduced costs for current labor flows between former colonies of the same hegemon and between a former colony and the hegemon itself.

The additional explanatory power of gravity variables would still not account for the idiosyncratic cases of very high or very low immigration, which are evident in Figure 1 . Highinflow countries include Switzerland, whose long history of neutrality has made it the headquarters for international organizations that hire large numbers of foreign diplomats and other professionals, and Israel, whose national identity is predicated on encouraging immigration of those of Jewish descent (Friedberg 2001). Korea and Japan discourage immigration, ostensibly to maintain cultural homogeneity (Cornelius, Martin, and Hollifield 1994), resulting in low labor inflows. These historical features, which are manifest in policies 
that would be transparent to any person attempting to emigrate to these destinations, are difficult to measure empirically and hence end up in the regression residual.

Another shortcoming of the gravity model, at least as conventionally applied, is a focus on current income as a predictor for bilateral migration. Because migration is a long-lived decision, individuals are likely to evaluate the extended prospects for their livelihoods in alternative destinations, as Sjaastad (1962) proposed. Obvious additional factors that affect future earnings include total factor productivity growth and capital accumulation, which are hard to forecast far into the future. Domestic labor-supply growth, on the other hand, is eminently forecastable. Current differences in birth rates between countries foretell how relative labor supplies - holding immigration constant-will change 15 to 20 years hence, when today's newborns enter the labor force. Because birth rates change much less abruptly than investment or innovation, demographers are able to forecast changes in birth rates two to three decades into the future with considerable accuracy (O'Neil, Scherbov, and Lutz 1999; Lutz, Sanderson, and Scherbov 2001). Thus, current population growth is informative about what domestic labor supplies would look like 40 to 50 years from now, with no further flows of international migrants. In later sections, we use this insight to estimate an augmented gravity model of bilateral migration that accounts for both current relative incomes and expected future relative incomes as captured by anticipated changes in domestic labor supplies.

Figure 1 illustrates the potential pitfalls of using only current income alone as an indicator of coming migration. If one were to utilize nothing other than the residuals from the regression plot, it would appear that the United States is poised for relatively high immigration in the future. Its foreign-born share of the US population at 12.9 percent is similar to that of the large countries of Europe: even with Germany; slightly above France, the Netherlands, and the United Kingdom; and slightly below Spain. Yet, US per capita GDP exceeds that of these other nations by substantial amounts. Moreover, the relatively high labor-market rewards to moreeducated workers in the United States, in both pre-tax and post-tax terms, gives it a strong advantage in attracting more-skilled labor (Grogger and Hanson 2011). We will see next that a different picture of migration pressures emerges once we examine the composition of bilateral immigration stocks in major destination countries. These reveal that it is Europe, not the United States, in which the potential for substantial future inflows appears greatest.

\section{Bilateral Migration Stocks in OECD Countries}

To study bilateral migration, we use data on the numbers of the foreign born by country of birth from the Database on Immigrants in OECD Countries (DIOC). ${ }^{1}$ Following categories

\footnotetext{
${ }^{1}$ See http://www.oecd.org/els/mig/databaseonimmigrantsinoecdcountriesdioc.htm. For most countries, the source for the DIOC is a decennial census (OECD, 2008), whose large sample sizes permit the
} 
used in the DIOC, we focus on individuals between ages 15 and 64. This range is more expansive than the definition of the working-age population that is conventional in US or European labor-market analysis. Whereas many high-income nations require children to stay in school until age 18, in most lower-income countries mandatory schooling ends between grades six and nine. It is around age 15 that emigration rates in major sending countries pick up noticeably, as youths leave school and begin to seek work (McKenzie and Rapoport 2007).

Table 1 summarizes the number of immigrants living in the ten largest OECD migrantreceiving countries as of 2010, which is the most recent year for which the DIOC has comprehensive data on bilateral migration stocks. Considering absolute numbers, rather than the foreign-born population shares in Figure 1, the United States is by far and away the dominant destination country for international migrants. The 32.8 million working-age immigrants who resided in the United States in 2010 were 41.6 percent of all foreign-born individuals living in an OECD country. (For perspective, the United States accounted for one-quarter of the total OECD population in 2010.) Other destination countries are distant runners up. Next in line are Great Britain, with 7.9 percent of the working-age immigrants that reside in OECD countries; Spain, with 6.2 percent; and Canada, with 6.0 percent.

Equally impressive is that a single source country, Mexico, accounts for just under onethird of US working-age immigrants. The 10.2 million individuals born in Mexico and living in the United States accounted for fully 13.1 percent of all immigrants living in an OECD country in 2010. Remarkably for a country as large as Mexico, these immigrants were equal in number to 13.5 percent of Mexico's working-age population. Indeed, the Mexico-to-US migrant flow is one of the largest international migration episodes that the world has seen. Any substantial change in pressures for migration from Mexico to the United States could thus have a major impact on US immigrant presence. Ten of the 20 next largest immigrant groups in the OECD also reside in the United States. They include migrants from high-population countries (China, India), low-income countries close to the United States (Cuba, the Dominican Republic, El Salvador, Guatemala), and countries in which US military presence has facilitated immigration (Germany, Korea, Philippines, Vietnam). Though China's and India's total volumes of migration to the United States are large, their emigration rates are low.

The United States is far from alone in having a few countries play a prominent role in its immigration picture. Poles, Indians, and Pakistanis together are 24.2 percent of UK immigrants; Romanians and Moroccans combine to represent 26.0 percent of immigrants in Spain; Algerians and Moroccans account for 28.0 percent of working-age immigrants in France; and individuals

estimation of bilateral migrant stocks for the majority of sending countries. Measuring bilateral migration is problematic in Germany, which rarely conducts a census. The German data in the DIOC are based on labor force surveys, which suppress country of birth for immigrants from smaller origin nations. As a consequence, we lack data on bilateral stocks that account for two-fifths of German immigration. 
born in Turkey and Poland are 27.4 percent of German immigrants. ${ }^{2}$ The Romanians living in Italy and Spain are equivalent to 10.0 percent of the population of working age in Romania and Poles living in Germany and the United Kingdom equal to 5.7 percent of Poland's working-age residents. Flows of these magnitudes mean that labor-market shocks in these sending countries have potentially significant consequences for destination economies, and vice-versa.

\section{Drivers of International Migration}

Following the logic of the gravity model, it is no accident that many of the largest bilateral migration stocks involve nearby countries. There is both motive and opportunity for migration from Romania to Italy, Poland to Germany, and Morocco to Spain. The enlargement of the European Union in 2004 to countries across eastern Europe, which eliminated immigration restrictions on accession countries, further expanded opportunities for migration from eastern to western Europe (Elsner 2013). Also consistent with the gravity framework, colonial history has eased the movement of Algerians and Moroccans to France, Ecuadorans to Spain, and Indians and Pakistanis to the United Kingdom (Bertoli, Moraga, and Ortega 2011). Other flows, however, involve happenstance. The Turkish migration to Germany began in the 1960s, when West Germany sought foreign guest workers to fill low-wage positions during a period of soaring economic growth. This first generation of immigrants created family and kinship networks that facilitated immigration in later decades (Pischke and Velling 1997).

Motive and opportunity, however, are far from sufficient conditions for migration to occur. The United States and Mexico, which share a 2,000-mile land border, have long had widely divergent incomes. In 1960, per capita GDP (PPP adjusted) in the United States was triple that in Mexico, a ratio that remained essentially unchanged during the following two decades - yet there was only a modest migration response. As a share of Mexico's national population, the number of the Mexicans living in the United States stood at 1.5 percent in 1960 and 3.2 percent twenty years later. In 1980, immigrants from Mexico accounted for just 1.0 percent of the US population.

What sparked substantial labor flows from Mexico to the United States was the onset of the Mexican debt crisis of the 1980s and the "lost decade" of economic stagnation that followed

\footnotetext{
${ }^{2}$ In Table 1, the foreign-born are 7.6 percent of Germany's working-age population, which seems low compared to 13.0 percent of Germany's total population as seen in Figure 1. This discrepancy reflects missing data on bilateral migration for Germany's smaller migrant-sending countries. To arrive at estimated of the share of total German immigrants given in the text, we inflate the total number of German immigrants reported in panel A of Table 1 by an adjustment factor that accounts for "missing" bilateral migrants in the OECD data (where this conversion factor is 13.0-the percentage of the foreignborn in German's total population in Figure 1-divided by 7.6-the percentage of the foreign-born in German's working-age population in Table 1).
} 
(Hanson and Spilimbergo 1999). Between 1982 and 2000, the ratio of US-to-Mexico per capita GDP rose by over one-and-a-half times, from 2.3 to $3.8 .{ }^{3}$ Financial crises are common triggers of migration episodes (Yang 2007; Bertoli, Moraga, and Ortega 2013), as are political upheaval and military conflict (Hanson and McIntosh 2012). However, temporary shocks need not induce permanent migration. During the Mexican Revolution (1911-1920), approximately 700,000 Mexicans, or 5 percent of the population, fled to the United States. By the late 1920s, a large fraction had returned home (Cardoso 1980; Durand, Massey, and Charvet 2000).

To sustain international migration, it helps if individuals expect that economic conditions will diverge between origin and destination countries in coming years. In sending nations, increases in domestic labor supply, relative to abroad, are one impetus for such expectations. Between 1940 and 1960, the US baby boom matched rapid population growth in Mexico. In the ensuing two decades, birth cohorts in Mexico continued to grow in size, while the annual number of births in the U.S fell in both relative and absolute terms. The consequence was that between 1960 and 1980 the relative size of US-Mexican birth cohorts dropped precipitously from 4:1 to less than 2:1, a shift which meant that Mexico's relative labor supply was expanding at mach speed in the 1980s just as its economy staggered.

The contribution of labor-supply growth to international migration is evident not just at the national level but also across regions within economies. Mexico's demographic transition occurred unevenly across space. First affected were richer states along the US border and around Mexico City; last affected were poorer states in central and southern Mexico. The Mexican migrants who moved north, while roughly similar in educational attainment to workers who stayed behind (Chiquiar and Hanson, 2005; Kaestner and Malamud, 2013), were not drawn randomly from across Mexico. They came disproportionately from states with preexisting migration networks (Munshi 2003; McKenzie and Rapoport 2007) and with relatively high labor-force growth. Exploiting this regional variation, Hanson and McIntosh (2010) find that relative labor-supply growth can account for two-fifths of Mexican migration to the US between the 1970s and the 1990s.

The Hot Spots with Population Pressures for Migration

The argument here suggests that when international borders also draw a line between nations with significant differences in population growth, pressures for migration will result. To illustrate this theme more concretely, we calculated national growth rates between 1970 and

\footnotetext{
${ }^{3}$ If education, labor market experience, or other sources of human capital are higher in destination than in sending countries, bi-national differences in per capita GDP will overstate the gain in income that an international migrant can expect to obtain. Holding constant observable worker characteristics, Clemens, Montenegro, and Pritchett (2008) estimate that in 2000 a young Mexico-born male with mean years of schooling would see his earnings rise by 2.5 times (in purchasing power parity-adjusted terms by migrating to the United States (where the US/Mexico per GDP ratio for that year is 3.8).
} 
1980 for the population of native-born individuals 0 to 14 years old. Data are from the United Nation's World Population Prospects (at http://esa.un.org/unpd/wpp/Download/Standard/Population). These growth rates determine the number of the native-born who would be coming of working age about 15 years hence-in this example, between the years 1980 and 1995. We then did a similar calculation using population forecasts for the years from 2040-2050. The results suggest how the population pressures for migration will change over time. ${ }^{4}$ Figures $2 \mathrm{a}$ and $2 \mathrm{~b}$ map the outcome of this exercise, where countries with high population growth are shown in dark grey and countries with low population growth are shown in light grey.

In the 1970s, there was a stark North-South divide in the growth of the young population. Most richer countries including the United States, Canada, and most nations of western Europe show a decline in the relevant population from 1970 to 1980. Declines in these countries were the result of the end of the post-World War II baby boom and the lower birth rates that had taken hold by roughly 1960. Australia, Ireland, Japan, and Spain were the only higher-income countries with positive growth in the number young people during the decade. In contrast, for most poorer countries the growth rates in the 0-14 age group were positive from 1970 to 1980 . The change in the youth population was positive to strongly positive in Latin America, Africa, the Middle East, and most of developing Asia. Growth in these regions was the result of continued high fertility combined with declines in infant mortality (Lee 2003). Among the countries in our data, only Cambodia, which suffered depopulation under the Khmer Rouge, Russia, which saw fertility plummet during the later years of the Soviet Union, and Suriname have negative growth in the number of 0 to 14 year olds during the 1970s.

Bilateral migration flows will tend to be high between countries that are neighbors and that occupy different ends of this population growth continuum. Based on our analysis of the 1970s, the Mexico-US border shows up as one evident hot spot for migration. Other migration hot spots in this time period include Europe and North Africa and the Middle East. In particular, booming growth in the youth populations of Algeria, Libya, Morocco, and Turkey contrasted with sagging youth populations north of the Mediterranean, which helped fuel migration into Europe in the 1990s and 2000s. Other adjoining countries with both underlying age 0-14 population growth differentials in the 1970s and also meaningful differences in per capita income include South Africa and its immediate neighbors, and Russia and most of the nations of Central Asia. In recent decades, there were substantial migration flows within each of these groups (Özden, Parsons, Schiff, and Walmsley, 2011). ${ }^{5}$

\footnotetext{
${ }^{4}$ The UN Population projections by age and sex start in 2015 and are done using the open source CRAN $\mathrm{R}$ package bayesPop as documented in Raftery, et al. (2012). We use the 'Zero Migration' variants which do not attempt to forecast future migration rates in projecting age cohort sizes.

${ }^{5}$ One anomaly is the Persian Gulf. Growth in the young population in the 1970s and 1980s was rapid in Saudi Arabia and the United Arab Emirates, yet these countries became importers of labor from South
} 
Looking forward, the geography of population growth will be very different than in the past, which also suggests that the population pressures for migration will shift. To construct the growth rate of the age 0-14 population between 2040 and 2050, we used projections from the United Nation's World Population Prospects. The UN Population Division constructs forecasts both including and excluding expected immigration in the future. Because our interest is ultimately in seeing how changes in the size of birth cohorts affects pressures for migration, we restrict our attention to UN forecasts that leave out projected future immigration.

The decade of the 2040s is far enough in the future for present trends of declining fertility in the Americas, Europe, and East Asia and of more stable fertility in Sub-Saharan Africa and parts of the Middle East to produce substantial differences in population growth between countries. By the 2040s, the North-South divide in population growth will be gone. Instead, the differences in population growth of the 0-14 age group will be primarily regional in nature. For example, essentially all countries of North and South America show declines in the age 0-14 population during the 2040s, with the exceptions of Guatemala and French Guiana, Consequently, the US-Mexico border no longer appears as a hotspot for migration pressures in coming decades.

Most of Europe will have negative growth in the population of 0-14 year olds in the 2040s, with the exceptions of Sweden and the United Kingdom, whose current high-fertility immigrant populations will keep future fertility from declining as rapidly as on the rest of the continent. Morocco, Turkey, and Saudi Arabia also have a projected decline in their age 0-14 native-born population during the 2040s, reflecting projected fertility declines in the more cosmopolitan countries of the Muslim world. However, nearby are the high-fertility countries of North Africa and Sub-Saharan Africa. The Mediterranean thus appears likely to continue to be a hotspot for international migration out to mid-century. Further, new population-growth gradients seem ready to emerge within North Africa and the Middle East, contributing to pressures for intraregional migration. ${ }^{6}$

In this scenario, a question mark hangs over Asia. East, Southeast, and South Asia all show a decline in the age 0-14 population in the 2040s, with the exceptions of Vietnam and Papua New Guinea. The nations in this region have little history of large immigrant inflows. They are also far from high-population-growth areas in Africa. Both factors would suggest that

\footnotetext{
Asia, Egypt, and elsewhere in the Middle East in later decades (Jain, Zacharia, and Oommen 2015). Low rates of labor-force participation among the native-born in Gulf states may account for the unusual combination of high growth in the native-born working-age population and high immigration.

${ }^{6}$ Perhaps surprisingly, Russia shows up as a country with positive projected population growth. This reflects the tendency of projection models to impose some degree of regression to the mean; for example, China's actual male/female gender imbalance of 1.17 in 2015 is predicted to return linearly towards the global average over the coming decades. Following Russia's demographic collapse that began in the 1980 s, forecasts push the country to have makeup population growth in the future.
} 
migrant inflows in Asia may stay low in the future. Yet, few nations in Asia have to this point experienced a demographic reality that entails persistent population decline. This coming drop may create pressures for immigration policies that are more open than in the past.

\section{Population Pressures for Migration in the Past and Future}

To formalize the connection between population pressures and migration, we estimate a simple gravity model of bilateral migration flows. We then use this model to project migration out to mid-century, based on forecasted growth of populations coming of working age.

\section{A Gravity Model for Migration Without the Legacy of Previous Migration}

The standard framework for bilateral migration is the gravity equation, which posits that the movement of labor from one location to another is a function of relative earnings in the two locations, economic opportunities in alternative destinations, and bilateral migration costs (for example, Bertoli and Moraga 2013). Here, we describe one strategy for estimating a model of this kind, and what it implies for how the population pressures for migration will evolve in the future. In an online Appendix available with this paper at http://e-jep.org, we discuss robustness and specification checks for this approach.

We look at the migration rate in a disaggregated way: specifically, the migration rate $y_{c s d, t}$ is the percentage of age-gender group $c$ from sending-country $s$ that has migrated to destination-country $d$ as of year $t$; for example, the share of 15 to 24 year-old men born in Mexico who are residing in the United States in 2000. The dependent variable is the change in the age-specific net emigration rate from a sending country to an OECD destination during the 2000s: for example, the percentage emigration rate to the US for Mexico-born men who were 25 to 34 years old in 2010, $y_{c s d, 2010}$, minus that for those who were 15 to 24 years old in 2000, $y_{c s d, 2000}$. Using those who were 15-54 in 2000, we have 410 -year birth cohorts, 2 genders, and 3,457 sending-destination pairs covering 175 sending countries and 25 destinations. Missing data on GDP for early cohorts from some developing countries reduces the usable sample size from the potential 27,656 observations to the actual of 18,297. By estimating the model in firstdifferences, we sweep out time-invariant migration barriers in a destination that are specific to a sending country (for example, visa policies that favor particular origin nations).

Our starting-point regression has nine explanatory variables, plus a constant term. The first is a demographic term based on differentials in the size of age-specific birth cohorts. The second is an incentive term based on income differentials between countries. The next four terms are commonly included in gravity models: they are the (the log of) distance between countries where migration occurred, whether the two countries where migration occurred share a contiguous border, whether the two countries where migration occurred had a colonial 
relationship; and whether they share a common language. The final three terms are fixed effects for the age cohort, the sending country, and the destination country, which are intended to capture time trends in each of these dimensions. We will say a few words about each of these. But we will then find that it is important to include one more economic factor, made up of interaction terms that seeks to capture whether dyads of countries have been more or less closely linked by migration in the past, thus laying the groundwork for higher migration by the younger cohorts in the future.

The first regression term and the key explanatory variable for our analysis can be thought of a seeking to capture the relative abundance of labor in the sending and receiving economies. We calculate the relative size of an age-gender cohort in the sending and destination countries, $\frac{L_{c s, t}}{L_{c d, t}}$, and we look at how this changes over time. For example, we would look at the $\log$ Mexico/US birth cohort ratios for those aged 15 to 24 in 2000, minus the log birth cohort ratio for those aged 15 to 24 in 1990. In effect, this term measures the panel changes in labor supply over time for a given age cohort. The use of this variable is a way of exploiting the long panel on birth cohort sizes in a context where we have only a cross-section of migration flows (2000-2010). This variable captures one way in which labor-market conditions in the two locations differed at the time the cohort entered the labor market.

The second regression term looks at relative per capita GDP (PPP adjusted) in the sending and destination countries, $\frac{w_{c s, t}}{w_{c d, t}}$. Specifically, we include the log of the GDP ratios in the year that a cohort turned 15. This focus on initial conditions captures the logic in Borjas (2006), in which adjustment costs constrain migration, such that labor flows do not equilibrate wages across locations instantaneously. ${ }^{7}$ Rather, labor moves from lower-wage to higher-wage locations over time in response to initial wage differentials.

The four standard gravity equation variables are the log geographic distance between the sending and destination countries and dummies for whether the countries of a dyad share a land border, a common language, and past colonial linkages. These variables can be thought of as controls for bilateral migration costs.

By virtue of the first-difference specification, we can use fixed effects for age/gender cohort, sending-country, and destination-country, $\delta_{c}, \delta_{s}$, and $\delta_{d}$ to capture differential time trends along these dimensions, perhaps representing differential exposure to economic shocks,

${ }^{7}$ To avoid reverse causality from migration to labor-market conditions, we measure relative labor supply for an age group in the birth year (or as close to the birth year as decennial censuses allow), and we measure relative per capita GDP around the year that an age group would have entered the labor force, which we take to be age 15. 
over the 2000 to 2010 period. More specifically, sending-country fixed effects help control for changes in the alternative labor-market opportunities of prospective migrants, while destination-country fixed effects absorb changes in immigration barriers in the destination that are common across origins. ${ }^{8}$

The first column of Table 2 presents the results from this regression. The first column shows contrary to our prior work in the Americas (Hanson and McIntosh 2012), global migration is not effectively absorbing population in rapidly-growing countries: the coefficient on labor supply growth is negative and significant at the 10 percent level. However, consistent with previous literature, the migration rate is higher for age groups confronting larger differences in per capita GDP in the destination versus the sending country. For birth cohorts ten years apart (that is, the same age group observed in successive decades), the one facing a 10 percent higher destination-sending country income ratio in the year of labor-market entry would have a 0.001 percentage-point lower bilateral migration rate (relative to a weighted sample mean flow migration rate of .02 percent between 2000 and 2010, with standard deviation of .23).

\section{A Model Including Interactions with Earlier Migration}

Bilateral migration is lumpy, as was apparent earlier in Table 1. Migrants from particular sending countries tend to cluster in particular destinations. Some of this lumpiness is due to gravity factors. Because Spain is the closest high-income country to Morocco, it is a favored destination for Moroccan emigrants. Clustering may also embody enclave effects, in which earlier generations of migrants ease assimilation for later generations, or built-in persistence created by migration policy, such as family-reunification provisions that give the kin of existing residents preferential access to visas. The presence of migration networks means that initial labor-market conditions may affect bilateral migration. We wish to take these dyadspecific migration networks into account (Munshi 2003; McKenzie and Rapoport 2007; Beine, Docquier, and Özden 2011). Thus, we seek to interact initial labor-market conditions with the kernels around which networks may form.

${ }^{8}$ For those who would like to see their regressions written out in algebraic form, rather than the description in the text, it is: $y_{c s d, t+1}-y_{c s d, t}=\delta_{c}+\delta_{s}+\delta_{d}+\alpha\left[\ln \frac{L_{c s, t}}{L_{c d, t}}-\ln \frac{L_{c s, t-1}}{L_{c d, t-1}}\right]+$ $\beta_{1}\left[\ln \frac{w_{c s, t}}{w_{c d, t}}\right]+\beta_{2}\left[\ln \frac{w_{c s, t}}{w_{c d, t}}\right]^{2}+++\varepsilon_{c s d}$, where $\tau_{s d}^{i}$ is the value for gravity variable $i$ (i.e., distance, language, common border, or colonial linkages) corresponding to sending-country $s$ and destination-country $d$. 
In a first approach to capture this interaction, we calculate the stock of sending-country migrants over age 50 in the destination as of 2000. Since most international migration occurs when individuals are young, over-age-50 migrants in 2000 represent inflows that occurred in the 1960s, 1970s and 1980s, when many networks were first being filled out. We use this measure because many dyads do not have available and age-specific bilateral migration data years before 2000, so we lack the ability to measure immigration networks comprehensively in earlier years. More specifically, we measure these migration networks, using dummy variables that indicate whether the over-age-50 bilateral migration rate for a dyad was in the top 50 percent, top 20 percent, or top 5 percent across all dyads in 2000.

Our primary interest here is in the relationship between relative labor supply in the sending and destination country and bilateral migration. As noted earlier, the uninteracted effect of bilateral labor supply is negative, indicating that in countries without strong migrant networks, relative labor supply has little effect (indeed, a counterintuitively negative effect) on migration. However, the impact of relative labor supply on bilateral migration becomes strongly positive once interacted with indicators for migration networks. In columns 2, 3, and 4, we add the dummy variable for previous over-50 migration in the dyad, as well as an interaction term between this and the change in the age-specific birth cohort ratio. For birth cohorts ten years apart, the one in which the sending-destination population ratio change was 10 percent larger would have a 0.006 percentage-point (column 2), a 0.02 percentage-point (column 3), or a 0.08 percentage-point (column 4) higher bilateral migration rate, depending on whether initial migration networks were above the median (over-age-50 bilateral migration rate in 2000 in the top 50 percent), strong (over-age-50 bilateral migration in the top 20 percent), or very strong (over-age- 50 bilateral migration in the top 5 percent). All of these interactions are statistically significant at conventional levels.

When the existence of earlier migration networks between two countries is taken into account by using the size of the earlier migrant group, the relative supply of labor does have an effect on migration patterns. Another way to take the earlier migration networks into account is to use the interactions with each of the four gravity variables and the 1990-2000 age-specific birth cohort ratio. The relationship between bilateral migration and sending-destination country population ratios for an age group is stronger for dyads that are geographically more proximate (column 5), contiguous (column 6), or share a colonial language or common language (columns 7 and 8), where all of these interactions are precisely estimated. F-tests at the bottom of the table show that the effect of labor supply differentials are significantly positive within most of these well-networked dyad relationships. 
Population Growth and Migration in the Future

Our next step is to utilize these results for understanding migration pressures in the future. We run a new regression (reported in the online Appendix) in which we add to the specification in column (1) all seven of the covariates used across columns (2) to (8) at the same time, as well as the interactions between these covariates and the relative labor supply effect. ${ }^{9}$ This regression thus includes in a single specification all of the interactions that are shown individually in Table 2, and provides a way of predicting panel changes in bilateral migration over the coming decades. ${ }^{10}$ We then combine our regression coefficient estimates with laborsupply projections derived from UN population counts and GDP per capita projections derived from IMF forecasts to predict the dyadic decadal migration flows that will occur for each 10year age cohort over 2010-2050. ${ }^{11}$ We add these decadal inflows to any pre-existing migrant stocks to calculate future stocks of migrants from each origin in each destination in each decade. Where we observe stocks of migrants at the beginning of the period, we add the forecasted flows to these stocks. These predicted stocks can then be summed across gender, age, origin, or destination to calculate totals of foreign-born migrants aged 15-54 for each decade, as shown in Figure 3.

Several details of the forecasting exercise merit further discussion. By restricting the sample to be individuals aged 15-54 in the initial year of a decade and dividing these individuals into 10-year age groups, we forecast a total of 16 decadal migration rates for each sending-destination dyad. ${ }^{12}$ Because there is an assumed a 15-year lag between when an individual is born and when he enters the labor force, our projected changes in labor supply combine cohorts already born and cohorts yet to be born. This time lag also means that only two of the seven birth cohorts represented in the analysis were born after 2015. Thus, most of the changes in labor supply that we incorporate in the forecasts are based on population growth that has already occurred. We allow initial relative per capita GDP to change over time, based on IMF forecasts of annual GDP growth for 2018-2020 (http://www.imf.org/external/datamapper/index.php) which we assume are sustained out to

\footnotetext{
${ }^{9}$ We also add to the specification the square of relative GDP per capita at age 15, which helps account for non-linearities in how income differentials affect migration. Whether or not we include this squared income term has little impact on the forecasts. An online Appendix provides further discussion. ${ }^{10}$ In an online Appendix, we discuss additional forecasts based on alternative assumptions regarding future GDP growth that we performed to check the robustness of our findings. These alternative forecasts yield predicted migration flows that are very highly correlated with those shown in Figures 3 and 4 .

11 These time periods are 2010-2020, 2020-2030, 2030-2040, and 2040-2050.

12 The birth cohorts (and the number of times they are used in the analysis) are those born in 1965-1974 (which are used once over the 2010-2020 period), 1975-1984 (used twice over 2010-2030), 1985-1994 (used three times over 2010-2040), 1995-2004 (used four times over 2010-2050), 2005-2014 (used three times over 2020-2050), 2015-2024 (used twice over 2030-2050), and 2025-2034 (used once over 2040-2050).
} 
2040. ${ }^{13}$ In the online Appendix we show that alternate GDP forecasts for low-income sending regions do not materially change our forecasts of future migration.

By holding all other regression variables constant in constructing migration forecasts, we are assuming that the impacts of distance, contiguity, common language, colonial linkages, and existing migration networks change at the same rate over future decades as they did between 2000 and 2010. These projections also incorporate our estimated age-and-gender group, sending-country, and destination-country fixed effects, which imposes the further assumption that time trends for migration along these dimensions are the same in future decades as they were during the 2000s. ${ }^{14}$ These are, of course, very strong assumptions. No decade is exactly like any other. Just as rapid productivity growth in developing countries could attenuate migration pressures, civil wars in Sub-Saharan Africa, climate-change-induced coastal flooding in Southeast Asia, or a return to macroeconomic instability in Latin America could exacerbate them. Further, new countries outside of the OECD could emerge as major destinations for international migrants, possibly attenuating flows into current high-income nations. In holding sending-country fixed effects constant, we implicitly assume that destination options for these countries are unchanged as well. Thus, we emphasize that our intent is not to produce projections of future immigration levels around which policymakers should make decisions. Rather, we simply wish to see how the changing population-growth patterns over the next few decades will affect pressures for international migration.

Figure 3 shows the projected first-generation migrant totals (aged 15-64) for the major destinations through 2050. Destinations are heterogeneous in the population growth to which their current migrant stocks expose them, via the interaction between future changes in relative labor supply and the migrant-network indicators. The United States sees relatively steady counts of immigrants for the next three decades, which means that arriving young immigrants replace those who age out of the working-age population with little net change in the total stock. Three European destinations are heavily exposed to rapidly-growing sending countries and hence see tremendous future growth in immigration pressure: the United Kingdom, Spain, and Italy. Germany, exposed in the past primarily to relatively wealthy Turkey and Eastern Europe, sees a rapid decline in immigrant stocks over the coming 30 years in these calculations. However, it should be noted that our analysis precedes the recent burst of asylum-driven

\footnotetext{
${ }^{13}$ Current IMF GDP growth projections do not extend beyond 2020. As growth rates for most countries are constant after 2018, we assume by this time they have achieved the expected long-run rate of growth. ${ }^{14}$ For cohorts that have a 2010 migrant count observed, we add the predicted flows on to the realized levels to simulate migrant stocks into the future. For younger cohorts in which 2010 stocks are not observed, we begin to cumulate the predicted changes from 0 and total the predicted flows across decades to arrive at a predicted stock of migration. Because we use a linear model, in some dyads we predict negative migrant stocks (obviously not possible in reality). We retain these negative values in order to avoid biasing upward our totals when we sum predicted stocks across origins for a destination.
} 
migration into Germany, which establishes a base of migrants that is likely to attract future migrants from those countries for years to come.

Figure 4 drills down into migration inflows for six key destination countries in more detail. Because of the interactive effect between relative labor supply and the gravity and migrant-network indicators, forecasted dyadic migrant inflows in major destination countries differ markedly across major sending regions. In the left-hand column, we see the three rapidly growing destinations discussed above. The pattern in all three of these countries is relatively similar: future migration growth coming in equal measure after 2020 from a diverse set of destinations as well as from India and Sub-Saharan Africa. Spain and Italy, bordering the Mediterranean, are most exposed to migration from Africa. The United Kingdom, given its colonial linkages, is exposed to India and Sub-Saharan Africa in equal measure. Origins that play a large role in each of these destinations are Ethiopia, Philippines, and Nigeria (Italy); Nigeria, Morocco, and Brazil (Spain); and Philippines, Kenya, and Pakistan (United Kingdom). In the right-hand panels, we see three destinations that are less exposed to these rapidlygrowing origins. The United States sees Mexican immigrant counts drop from over 10 million in 2010 to a little over 2 million in 2050, alongside substantial drops in migrants from all other destinations except India, China, and Sub-Saharan Africa. France has relatively constant migrant stocks over time, resulting from a balance of declining migration from MENA and India and a small increase from sub-Saharan Africa. Germany displays the most pronounced decreases in future migration. These arise from a combination of origins with rapidly falling fertility-Turkey, Eastern Europe-and the implication of the positive interaction effects on variables such as colonial linkages and common language, of which Germany has few.

Consequently, the top origins our model predicts for Germany in 2050 are very distinct from the other destinations: France, Romania, Morocco, Somalia, Iraq, Poland, and Russia. Japan is not shown separately in Figure 4, but given its tradition of demographic isolationism and its distance from population growth centers, it remains a low-migration destination. By 2050, only China is projected by our model to have more than a few hundred thousand migrants in Japan.

\section{Discussion}

Given the prominent role of economic shocks, political conflict, and natural disasters in driving international migration, predicting long-term migration flows is a hazardous proposition. The demographic component of migration can be useful in such an exercise, because medium-run changes in labor supply are determined by population growth that has already occurred and longer-term differentials in population growth can be predicted with reasonably high accuracy. While changes in relative labor supply may not independently 
trigger large-scale migration, they set the stage for other types of shocks to set off the movement of large numbers of people across national borders.

This demographic way of thinking about immigration presents some stark implications. The era in which immigration levels are rising in a way that can feel out-of-control appears to be coming to an end in the United States, while it is be just beginning in the European Union, despite current political debates over immigration in the two domains that are quite similar. In the decades to come, America will find itself to be an island of slow population growth, insulated by the Atlantic Ocean from the motor of future population change in the Middle East and North Africa region and in Sub-Saharan Africa. These weakening immigration pressures follow a decade-long buildup in US immigration enforcement, which has raised annual government spending by tens of billions of dollars (Roberts, Alden, and Whitley, 2013). The completion of the demographic transition in most of the Western Hemisphere leaves one to wonder whether the benefits of continued US enforcement spending will justify its costs.

Europe, by contrast, will be surrounded by an eastern region comprised of Belarus, Ukraine, Russia, and Central Asia that is showing faster population growth, and it is separated only by the Mediterranean from the still-growing countries of North Africa and the booming populations of Sub-Saharan Africa. Thus, the conditions exist for western Europe to face strong population pressures for immigration for decades to come. Though the European Union allows the free movement of labor among member states, enforcement of immigration from outside the EU largely falls to individual countries, creating a free-rider problem. Spending by Italy on patrolling its coast line, for instance, ultimately affects the number of immigrant arrivals in northern Europe (Labanca, 2016). Given the potential for substantially greater immigration pressures in the future, one would expect that there would be positive gains to greater coordination of immigration policy within the EU.

The sending countries will have an alternative perspective on demographically driven international migration. The possibility of emigration served as a safety valve for the burgeoning populations of Southern Europe and Ireland as they went through their own demographic transformations in the late $19^{\text {th }}$ and early $20^{\text {th }}$ centuries (Hatton and Williamson, 2005). Our previous work shows that emigration to the United States, Canada, the United Kingdom, and Spain was strongly driven by demographic growth in Latin America and the Caribbean during the latter half of the $20^{\text {th }}$ century (Hanson and McIntosh, 2015). Strikingly, this pattern does not hold at a global level. Countries with rapidly growing populations that lack the benefits of proximity or large established migrant populations already in OECD destinations see lower emigration rates than more slowly-growing countries. This suggests that the migration safety valve may not operate for the next century's population growth in the way that it did in the past century. As an example, we predict the number of African-born firstgeneration migrants aged 15 to 64 outside of Sub-Saharan Africa to grow from 4.6 million to 
13.4 million between 2010 and 2050. During this same period, the number of working-age adults born in the region will expand from under half a billion to more than 1.3 billion, meaning that international migration would only absorb 1 percent of the overall population growth. Given an African continent expected to contain almost 4 billion people by 2100, the presence or absence of a migration safety valve would have profound implications. The coming half century will see absolute population growth in Sub-Saharan Africa five times as large as Latin America's growth over the past half century. Even with our predictions for expanded population pressures to certain countries of Europe, which are likely to be perceived as very high levels of immigration by those countries, Europe on track to absorb only a small share of Africa's population increase. 


\section{References}

Beine, Michel, Frederic Docquier, and Çağlar Özden. 2011. “Diasporas.” Journal of Development Economics, 95(1): 30-41.

Bertoli, Simone, and Jesús Fernández-Huertas Moraga. 2013. “Multilateral resistance to migration." Journal of Development Economics, 102: 79-100.

Blanchard, Oliver, and Lawrence Katz. 1992. "Regional Evolutions." Brookings Papers on Economic Activity, 1-75.

Borjas, George J. 2006. “Native Internal Migration and the Labor Market Impact of Immigration.” Journal of Human Resources 41: 221-258.

Cardoso, Lawrence. 1980. Mexican Emigration to the United States, 1897-1931. Tucson: University of Arizona Press.

Chiquiar, Daniel and Gordon Hanson. 2005. "International Migration, Self-Selection, and the Distribution of Wages: Evidence from Mexico and the United States." Journal of Political Economy, April 113(2): 239-281.

Clark, Ximena, Timothy Hatton, Jeffrey Williamson. 2007. “Explaining US Immigration, 1971-1998.” Review of Economics and Statistics, 89(2): 359-373.

Durand, Jorge, Douglas S. Massey, and Fernando Charvet. 2000. "The Changing Geography of Mexican Immigration to the United States: 1910-1996." Social Science Quarterly, 81(1): 1-15.

Durand, Jorge, Douglas S. Massey, and Rene M. Zenteno. 2001. "Mexican Immigration in the United States." Latin American Research Review 36(1): 107-127.

Friedberg, Rachel. 2001. "The impact of migration on the Israeli labor market." Quarterly Journal of Economics, 116: 1373-1408.

Hanson, Gordon H. 2006. "Illegal Migration from Mexico to the United States." Journal of Economic Literature, 44: 869-924.

Hanson, Gordon H. 2010. "International Migration and the Developing World.” In Dani Rodrik and Mark Rosenzweig, eds., Handbook of Development Economics, Vol. V, North Holland, 43634414 .

Hanson, Gordon H., Craig McIntosh. 2010. “The Great Mexican Emigration,” Review of Economics and Statistics, November 92(4): 798-810.

Hanson, Gordon H., Craig McIntosh. 2012. "Birth Rates and Border Crossings: Latin American Emigration to the US, Canada, Spain, and UK," Economic Journal, 122(561): 707-726.

Hanson, Gordon H., and Antonio Spilimbergo. 1999. "Illegal Immigration, Border Enforcement and Relative Wages: Evidence from Apprehensions at the US-Mexico Border." American Economic Review, 89(5): 1337-57. 
Hatton, Timothy J. and Jeffrey G. Williamson. 2006. "Refugees, Asylum Seekers, and Policy in Europe." In F. Foders and R. J. Langhammer, eds., Labor Mobility and the World Economy, Springer.

Hatton, Timothy J. and Jeffrey G. Williamson. 2005. “What Fundamentals Drive World Migration?” In. George J. Borjas and Jeff Crisp, eds., Poverty, International Migration, and Asylum, New York: MacMillan.

Jain, Prakash C., Ginu Zacharia Oommen. 2015. South Asian Migration to Gulf Countries: History, Policies, Development. Routledge.

Joppke, Christian. 1999. Immigration and the Nation-State: The United States, Germany, and Great Britain. Oxford: Oxford University Press.

Kaestner, Robert, and Ofer Malamud. 2014. "Self-Selection and International Migration: New Evidence from Mexico." The Review of Economics and Statistics, March 2014, 96(1): 78-91

Labanca, Claudio. 2016. “The Effects of a Temporary Migration Shock: Evidence of the Arab Spring Migration through Italy." Mimeo, UC San Diego.

Lee, Ronald. 2003. "The Demographic Transition: Three Centuries of Fundamental Change." Journal of Economic Perspectives, 17(4): 167-190.

Lutz, Wolfgang, Warren Sanderson, and Sergei Scherbov. 2001. “The end of world population growth." Nature, 412: 543-545.

Massey, Douglas S., R. Alarcon, Jorge Durand, and H. Gonzalez. 1987. Return to Aztlán: The Social Process of International Migration from Western Mexico. Berkeley: University of California.

Mayda, Anna Maria. 2008. "International Migration: A Panel Data Analysis of the Determinants of Bilateral Flows." Journal of Population Economics.

McKenzie, David and Hillel Rapoport. 2007. “Network Effects and the Dynamics of Migration and Inequality: Theory and Evidence from Mexico." Journal of Development Economics 84 (1): $1-24$.

Munshi, Kaivan. 2003. "Networks in the Modern Economy: Mexican Migrants in the US Labor Market." Quarterly Journal of Economics 118 (May): 549-97.

Stepler, Renee, and Anna Brown. 2015. "Statistical Portrait of Hispanics in the United States, 1980 - 2013." Pew Hispanic Center.

OECD. 2008. A Profile of Immigrant Populations in the 21st Century: Data from OECD Countries.

OECD. 2015. International Migration Outlook.

O'Neill, B. C., Scherbov, Sergei, and Wolfgang Lutz. 1999. "The long-term effect of the timing of fertility decline on population size." Population and Development Review, 25: 749-756. 
Ortega, Francesc, and Giovanni Peri. 2013. "The effect of income and immigration policies on international migration." Migration Studies.

Özden, Çağlar, Christopher R. Parsons, Maurice Schiff, and Terrie L. Walmsley. 2011. “Where on Earth is Everybody? The Evolution of Global Bilateral Migration 1960-2000." World Bank Economic Review, 25 (1): 12-56.

Pischke, Jörn-Steffen, and Johannes Velling. 1997. "Employment Effects of Immigration to Germany: An Analysis Based on Local Labor Markets." Review of Economics and Statistics, 79(4): 594-604.

Roberts, Bryan, Edward Alden, and John Whitley. 2013. Managing Illegal Immigration to the United States: How Effective is Enforcement? Council on Foreign Relations.

Raftery, A.E., N. Li, H. Ševčíková, P. Gerland, and G.K. Heilig. 2012. "Bayesian probabilistic population projections for all countries." Proceedings of the National Academy of Sciences, 109 (35):13915-13921

Sjaastad, Larry A. 1962. "The Costs and Returns of Human Migration." Journal of Political Economy, 70(1): 80 - 93.

Villarreal, Andrés. 2014. "Explaining the Decline in Mexico-US Migration: The Effect of the Great Recession." Demography, 51(6): 2203-2228.

Yang, Dean. 2006. “Why Do Migrants Return to Poor Countries? Evidence from Philippine Migrants' Responses to Exchange Rate Shocks." Review of Economics and Statistics, 88(4): 715735.

Yang, Dean. 2007. "International Migration, Remittances, and Household Investment: Evidence from Philippine Migrants' Exchange Rate Shocks." Economic Journal. 
Table 1: Counting First-Generation Migrants in 2010 (those born between 1946 and 1995).

Panel A. Total Migrant Counts by Destination.

\begin{tabular}{lccc} 
Destination: & $\begin{array}{c}\text { Total Migrants, } \\
\text { '000s: }\end{array}$ & $\begin{array}{c}\text { \% of Destination } \\
\text { Population }\end{array}$ & $\begin{array}{c}\text { \% of All Migrants } \\
\text { in Data }\end{array}$ \\
\hline USA & 32,782 & $15.7 \%$ & $41.6 \%$ \\
Great Britain & 6,208 & $15.0 \%$ & $7.9 \%$ \\
Spain & 4,880 & $15.3 \%$ & $6.2 \%$ \\
Canada & 4,697 & $19.8 \%$ & $6.0 \%$ \\
France & 4,569 & $11.2 \%$ & $5.8 \%$ \\
Italy & 4,120 & $10.6 \%$ & $5.2 \%$ \\
Germany & 4,019 & $7.6 \%$ & $5.1 \%$ \\
Australia & 3,454 & $23.1 \%$ & $4.4 \%$ \\
Japan & 1,259 & $1.6 \%$ & $1.6 \%$ \\
Netherlands & 1,223 & $11.0 \%$ & $1.6 \%$ \\
\hline \hline
\end{tabular}

Panel B. Total Migrant Counts by Origin.

\begin{tabular}{lccc} 
Origin: & $\begin{array}{c}\text { Total Migrants, } \\
\text { '000s: }\end{array}$ & $\begin{array}{c}\text { \% of Origin } \\
\text { Population }\end{array}$ & $\begin{array}{c}\text { \% of All Migrants } \\
\text { in Data }\end{array}$ \\
\hline Mexico & 10,406 & $13.7 \%$ & $13.2 \%$ \\
China & 3,036 & $0.3 \%$ & $3.9 \%$ \\
India & 2,957 & $0.4 \%$ & $3.8 \%$ \\
\hline \hline
\end{tabular}

Panel C. Migrant Counts by Origin/Destination Dyad:

\begin{tabular}{|c|c|c|c|c|c|}
\hline Destination: & Origin: & Count, '000s: & $\begin{array}{c}\% \text { of Destination } \\
\text { Population }\end{array}$ & $\begin{array}{c}\% \text { of } \\
\text { Origin Population }\end{array}$ & $\begin{array}{c}\text { \% of All Migrants } \\
\text { in Data }\end{array}$ \\
\hline \multirow[t]{12}{*}{ USA } & Mexico & 10,242 & $4.9 \%$ & $13.5 \%$ & $13.0 \%$ \\
\hline & India & 1,431 & $0.7 \%$ & $0.2 \%$ & $1.8 \%$ \\
\hline & Philippines & 1,296 & $0.6 \%$ & $2.2 \%$ & $1.6 \%$ \\
\hline & China & 1,089 & $0.5 \%$ & $0.1 \%$ & $1.4 \%$ \\
\hline & El Salvador & 1,022 & $0.5 \%$ & $27.2 \%$ & $1.3 \%$ \\
\hline & Puerto Rico & 993 & $0.5 \%$ & $40.2 \%$ & $1.3 \%$ \\
\hline & Vietnam & 914 & $0.4 \%$ & $1.5 \%$ & $1.2 \%$ \\
\hline & South Korea & 867 & $0.4 \%$ & $2.4 \%$ & $1.1 \%$ \\
\hline & Germany & 792 & $0.4 \%$ & $1.5 \%$ & $1.0 \%$ \\
\hline & Guatemala & 717 & $0.3 \%$ & $8.6 \%$ & $0.9 \%$ \\
\hline & Dominican Republic & 667 & $0.3 \%$ & $10.8 \%$ & $0.8 \%$ \\
\hline & Cuba & 603 & $0.3 \%$ & $7.6 \%$ & $0.8 \%$ \\
\hline \multirow[t]{4}{*}{ Germany } & Turkey & 1,021 & $1.9 \%$ & $2.1 \%$ & $1.3 \%$ \\
\hline & Poland & 870 & $1.6 \%$ & $3.2 \%$ & $1.1 \%$ \\
\hline & Russia & 780 & $1.5 \%$ & $0.8 \%$ & $1.0 \%$ \\
\hline & Kazakhstan & 611 & $1.2 \%$ & $5.4 \%$ & $0.8 \%$ \\
\hline \multirow[t]{3}{*}{ Italy } & Romania & 728 & $1.9 \%$ & $5.3 \%$ & $0.9 \%$ \\
\hline & Albana & 342 & $0.9 \%$ & $17.5 \%$ & $0.4 \%$ \\
\hline & Morocco & 315 & $0.8 \%$ & $1.5 \%$ & $0.4 \%$ \\
\hline \multirow[t]{3}{*}{ Mexico } & USA & 707 & $0.9 \%$ & $0.3 \%$ & $0.9 \%$ \\
\hline & Guatemala & 29 & $0.0 \%$ & $0.3 \%$ & $0.0 \%$ \\
\hline & Colombia & 12 & $0.0 \%$ & $0.0 \%$ & $0.0 \%$ \\
\hline \multirow[t]{3}{*}{ France } & Algeria & 699 & $1.7 \%$ & $2.9 \%$ & $0.9 \%$ \\
\hline & Morocco & 579 & $1.4 \%$ & $2.7 \%$ & $0.7 \%$ \\
\hline & Portugal & 379 & $0.9 \%$ & $5.4 \%$ & $0.5 \%$ \\
\hline \multirow[t]{3}{*}{ Spain } & Romania & 663 & $2.1 \%$ & $4.8 \%$ & $0.8 \%$ \\
\hline & Morocco & 636 & $2.0 \%$ & $3.0 \%$ & $0.8 \%$ \\
\hline & Ecuador & 392 & $1.2 \%$ & $4.2 \%$ & $0.5 \%$ \\
\hline \multirow[t]{3}{*}{ Great Britain } & Poland & 613 & $1.5 \%$ & $2.2 \%$ & $0.8 \%$ \\
\hline & India & 492 & $1.2 \%$ & $0.1 \%$ & $0.6 \%$ \\
\hline & Pakistan & 399 & $1.0 \%$ & $0.4 \%$ & $0.5 \%$ \\
\hline
\end{tabular}


Table 2: The Heterogeneity of Labor Supply Growth by Dyad Characteristics.

\begin{tabular}{|c|c|c|c|c|c|c|c|c|}
\hline \multirow{4}{*}{$\begin{array}{l}\text { Dependent variable is change in \% of } \\
\text { cohort migrated within dyad, } 2000-2010\end{array}$} & \multirow{3}{*}{$\begin{array}{c}\text { No } \\
\text { Interactions: }\end{array}$} & \multicolumn{7}{|c|}{ Columns show interaction between 1990-2000 change in log birth cohort ratios and the following covariate: } \\
\hline & & \multicolumn{3}{|c|}{$\begin{array}{l}\text { Dummy variable indicating that } 2000 \text { dyad-specific } \\
\text { migration rates among those over } 50 \text { are: }\end{array}$} & \multirow{3}{*}{$\begin{array}{l}\text { Log Distance } \\
\text { from Origin to } \\
\text { Destination } \\
\text { (5) }\end{array}$} & \multirow{3}{*}{$\begin{array}{c}\text { Origin and } \\
\text { Destination are } \\
\text { Continguous } \\
\text { (6) }\end{array}$} & \multirow{3}{*}{$\begin{array}{c}\text { Colonial } \\
\text { Relationship } \\
\text { (7) }\end{array}$} & \multirow{3}{*}{$\begin{array}{c}\text { Common } \\
\text { Language } \\
\text { (8) }\end{array}$} \\
\hline & & in top $50 \%$ & in top $20 \%$ & in top 5\% & & & & \\
\hline & (1) & (2) & (3) & (4) & & & & \\
\hline Interaction effect: & & $\begin{array}{l}0.0613^{* * *} \\
(0.023)\end{array}$ & $\begin{array}{c}0.186^{* * *} \\
(0.052)\end{array}$ & $\begin{array}{c}0.846^{* * *} \\
(0.287)\end{array}$ & $\begin{array}{c}-0.115^{* * *} \\
(0.035)\end{array}$ & $\begin{array}{c}1.122 * * * \\
(0.429)\end{array}$ & $\begin{array}{c}\text { 0.0762* } \\
(0.043)\end{array}$ & $\begin{array}{c}0.141^{* *} \\
(0.056)\end{array}$ \\
\hline $\begin{array}{l}\text { 1990-2000 change in age-specific } \\
\text { ln(origin/dest) birth cohort ratio }\end{array}$ & $\begin{array}{c}-0.0200^{*} \\
(0.011)\end{array}$ & $\begin{array}{c}-0.0418^{* * *} \\
(0.011)\end{array}$ & $\begin{array}{c}-0.0416^{* * *} \\
(0.010)\end{array}$ & $\begin{array}{c}-0.0298^{* * *} \\
(0.009)\end{array}$ & $\begin{array}{c}1.001 * * * \\
(0.309)\end{array}$ & $\begin{array}{c}-0.0327^{* * * *} \\
(0.011)\end{array}$ & $\begin{array}{c}-0.0220^{* *} \\
(0.011)\end{array}$ & $\begin{array}{c}-0.0364 * * * \\
(0.011)\end{array}$ \\
\hline Interacted variable from column title: & & $\begin{array}{c}-0.0179 * * \\
(0.008)\end{array}$ & $\begin{array}{c}-0.00101 \\
(0.014)\end{array}$ & $\begin{array}{c}0.153 \\
(0.095)\end{array}$ & $\begin{array}{l}-0.0188^{* * *} \\
(0.007)\end{array}$ & $\begin{array}{c}0.101 \\
(0.084)\end{array}$ & $\begin{array}{c}-0.0418^{* *} \\
(0.017)\end{array}$ & $\begin{array}{c}0.0532 * * * \\
(0.008)\end{array}$ \\
\hline Log Distance & $\begin{array}{c}-0.0329 * * * \\
(0.005)\end{array}$ & $\begin{array}{c}-0.0349 * * * \\
(0.005)\end{array}$ & $\begin{array}{c}-0.0305^{* * *} \\
(0.004)\end{array}$ & $\begin{array}{c}-0.0269 * * * \\
(0.005)\end{array}$ & & $\begin{array}{c}-0.0333^{* * *} \\
(0.005)\end{array}$ & $\begin{array}{c}-0.0325^{* * *} \\
(0.005)\end{array}$ & $\begin{array}{c}-0.0331^{* * *} \\
(0.004)\end{array}$ \\
\hline Contiguous & $\begin{array}{c}0.108 \\
(0.088)\end{array}$ & $\begin{array}{c}0.111 \\
(0.088)\end{array}$ & $\begin{array}{c}0.114 \\
(0.091)\end{array}$ & $\begin{array}{l}0.0952 \\
(0.078)\end{array}$ & $\begin{array}{c}0.131 \\
(0.094)\end{array}$ & & $\begin{array}{c}0.109 \\
(0.088)\end{array}$ & $\begin{array}{c}0.119 \\
(0.091)\end{array}$ \\
\hline Colonial Relationship & $\begin{array}{c}-0.0289 * * \\
(0.014)\end{array}$ & $\begin{array}{c}-0.0267^{*} \\
(0.014)\end{array}$ & $\begin{array}{c}-0.0451^{* * *} \\
(0.014)\end{array}$ & $\begin{array}{c}-0.0542 * * \\
(0.022)\end{array}$ & $\begin{array}{c}-0.0343^{* *} \\
(0.015)\end{array}$ & $\begin{array}{c}-0.0381^{* *} \\
(0.017)\end{array}$ & & $\begin{array}{c}-0.0336^{* *} \\
(0.015)\end{array}$ \\
\hline Common Language & $\begin{array}{l}0.0745^{* * *} \\
(0.009)\end{array}$ & $\begin{array}{c}0.0750 * * * \\
(0.009)\end{array}$ & $\begin{array}{c}0.0684^{* * *} \\
(0.009)\end{array}$ & $\begin{array}{c}0.0699 * * * \\
(0.008)\end{array}$ & $\begin{array}{l}0.0776^{* * *} \\
(0.010)\end{array}$ & $\begin{array}{l}0.0798^{* * *} \\
(0.010)\end{array}$ & $\begin{array}{c}0.0740 * * * \\
(0.009)\end{array}$ & \\
\hline $\begin{array}{l}\text { Log (origin/dest) GDP ratio in year } \\
\text { cohort turned } 15\end{array}$ & $\begin{array}{c}-0.00997^{*} \\
(0.005)\end{array}$ & $\begin{array}{c}-0.0101^{*} \\
(0.005)\end{array}$ & $\begin{array}{c}-0.00959 * \\
(0.005)\end{array}$ & $\begin{array}{c}-0.0103^{*} \\
(0.005)\end{array}$ & $\begin{array}{c}-0.00889 \\
(0.005)\end{array}$ & $\begin{array}{c}-0.0105^{*} \\
(0.005)\end{array}$ & $\begin{array}{c}-0.00980^{*} \\
(0.005)\end{array}$ & $\begin{array}{c}-0.0102 * \\
(0.005)\end{array}$ \\
\hline Constant & $\begin{array}{l}0.719 * * \\
(0.303) \\
\end{array}$ & $\begin{array}{l}0.764^{* *} \\
(0.303) \\
\end{array}$ & $\begin{array}{l}0.712^{* *} \\
(0.307) \\
\end{array}$ & $\begin{array}{l}0.660^{* *} \\
(0.305) \\
\end{array}$ & $\begin{array}{l}0.592^{*} \\
(0.310) \\
\end{array}$ & $\begin{array}{l}0.716^{* *} \\
(0.304) \\
\end{array}$ & $\begin{array}{l}0.717^{* *} \\
(0.303) \\
\end{array}$ & $\begin{array}{l}0.749 * * \\
(0.304) \\
\end{array}$ \\
\hline Observations & 18,297 & 18,297 & 18,297 & 18,297 & 18,297 & 18,297 & 18,297 & 18,297 \\
\hline R-squared & 0.081 & 0.082 & 0.085 & 0.101 & 0.084 & 0.095 & 0.081 & 0.082 \\
\hline F-test that (interaction+birth ratio) $=0$ & & 0.805 & 7.527 & 7.997 & 10.4 & 6.543 & 1.531 & 3.871 \\
\hline Prob $>F$ & & 0.370 & 0.006 & 0.005 & 0.001 & 0.011 & 0.216 & 0.049 \\
\hline
\end{tabular}

Analysis includes fixed effects for 10-year birth cohorts, origin, destination, and gender. Weighted by birth cohort population size to make results representative for all individuals born in the origin countries. Standard errors clustered at the dyad/gender/cohort level. ${ }^{* * *} \mathrm{p}<0.01,{ }^{* *} \mathrm{p}<0.05,{ }^{*} \mathrm{p}<0.1$. 
Figure 1: Income and Immigration in OECD Destination Countries

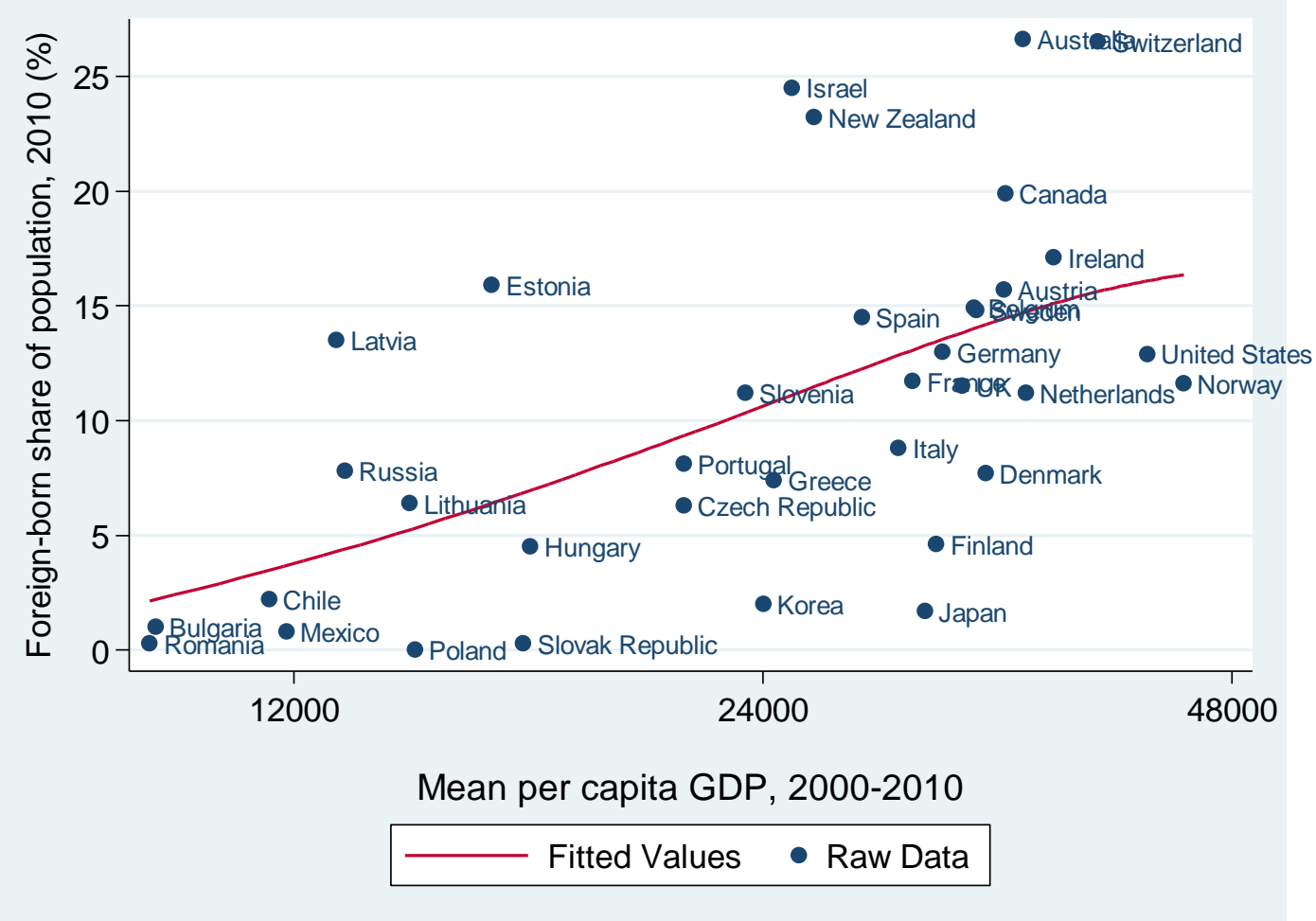

Note: Turkey is missing in Figure 1 due to the absence of OECD immigration data for the country. 
Figure 2a: Population Growth 1970-1980

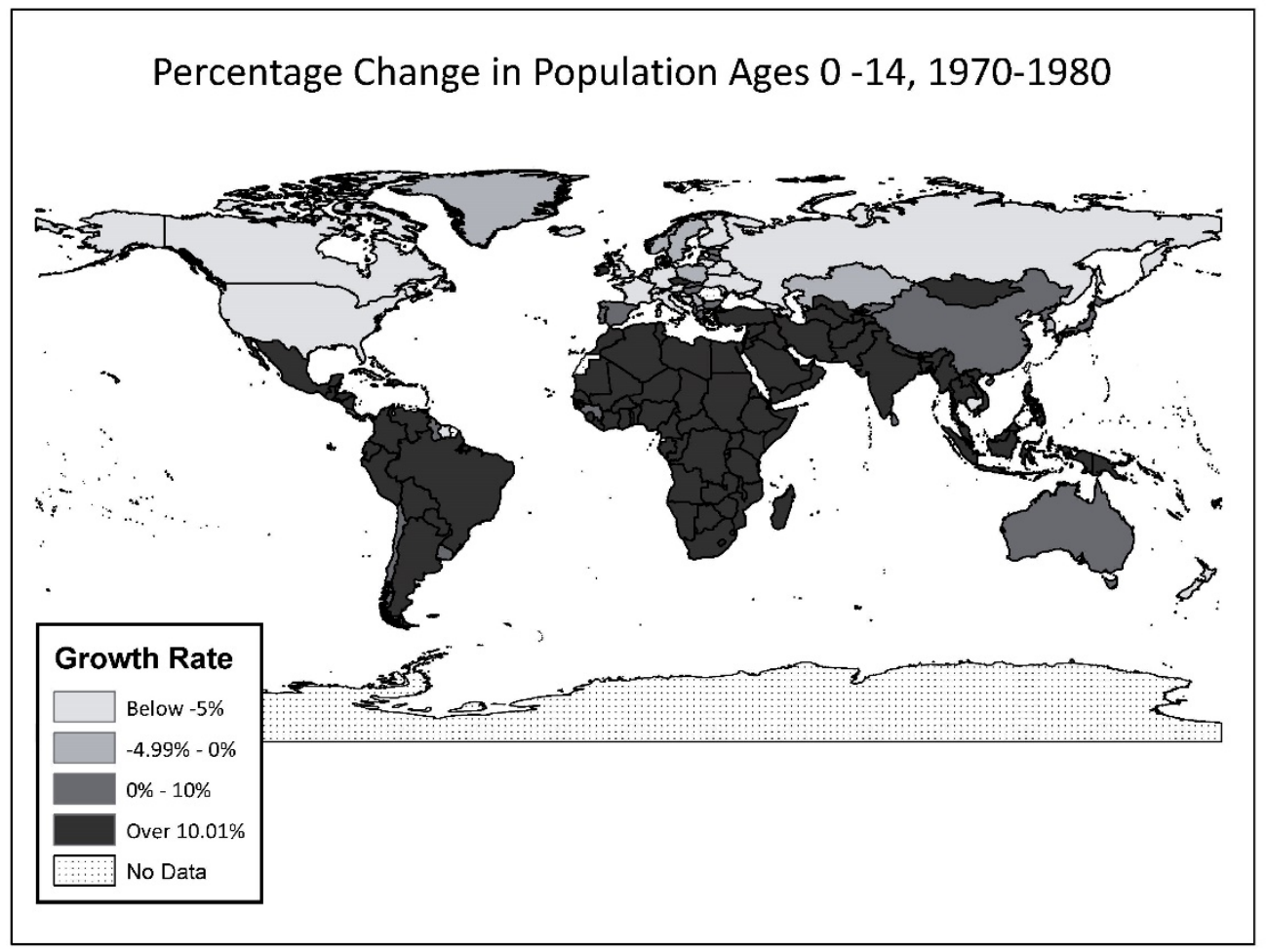

Figure 2b: Projected Population Growth 2040-2050

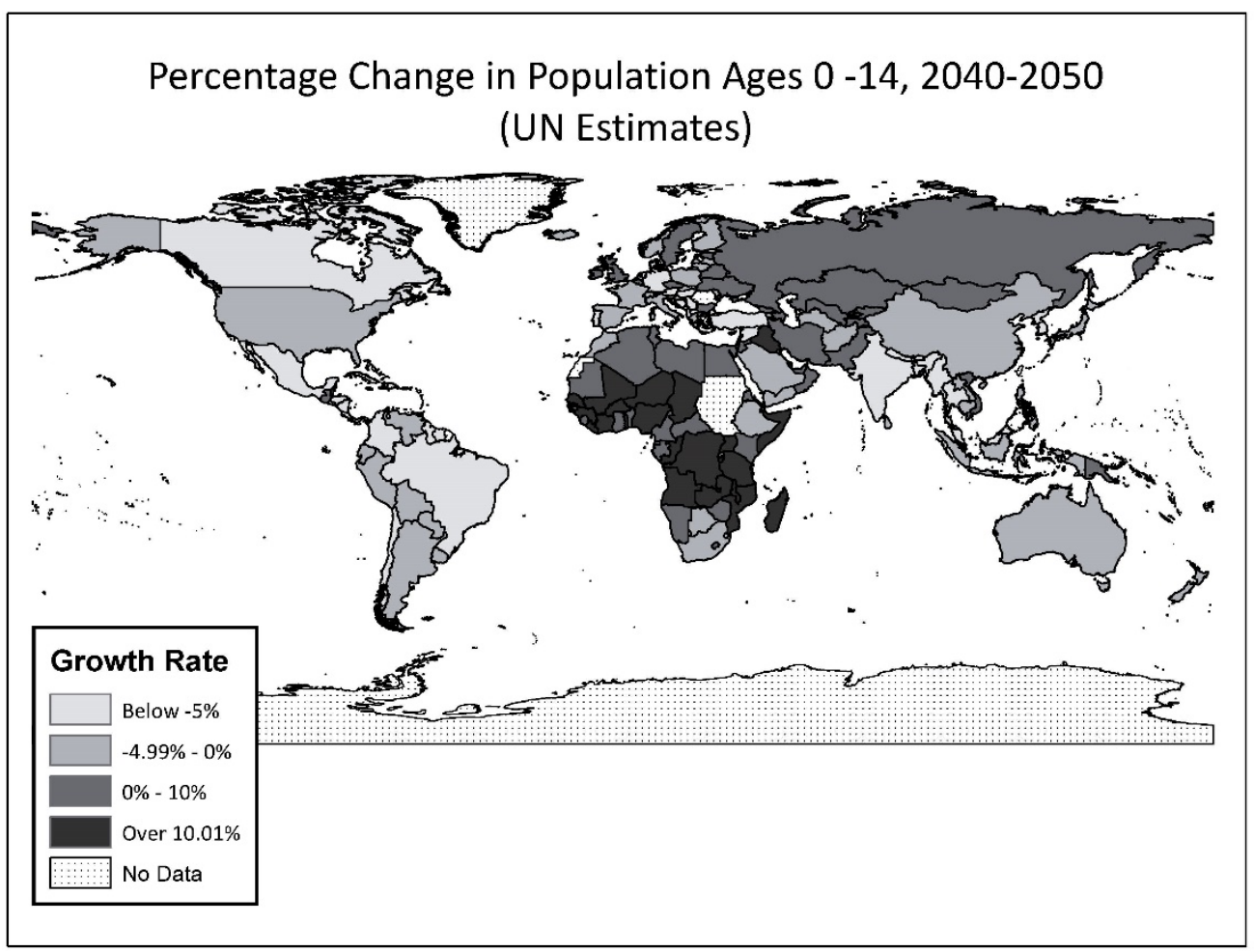


Figure 3. Predicted Migration by Destination

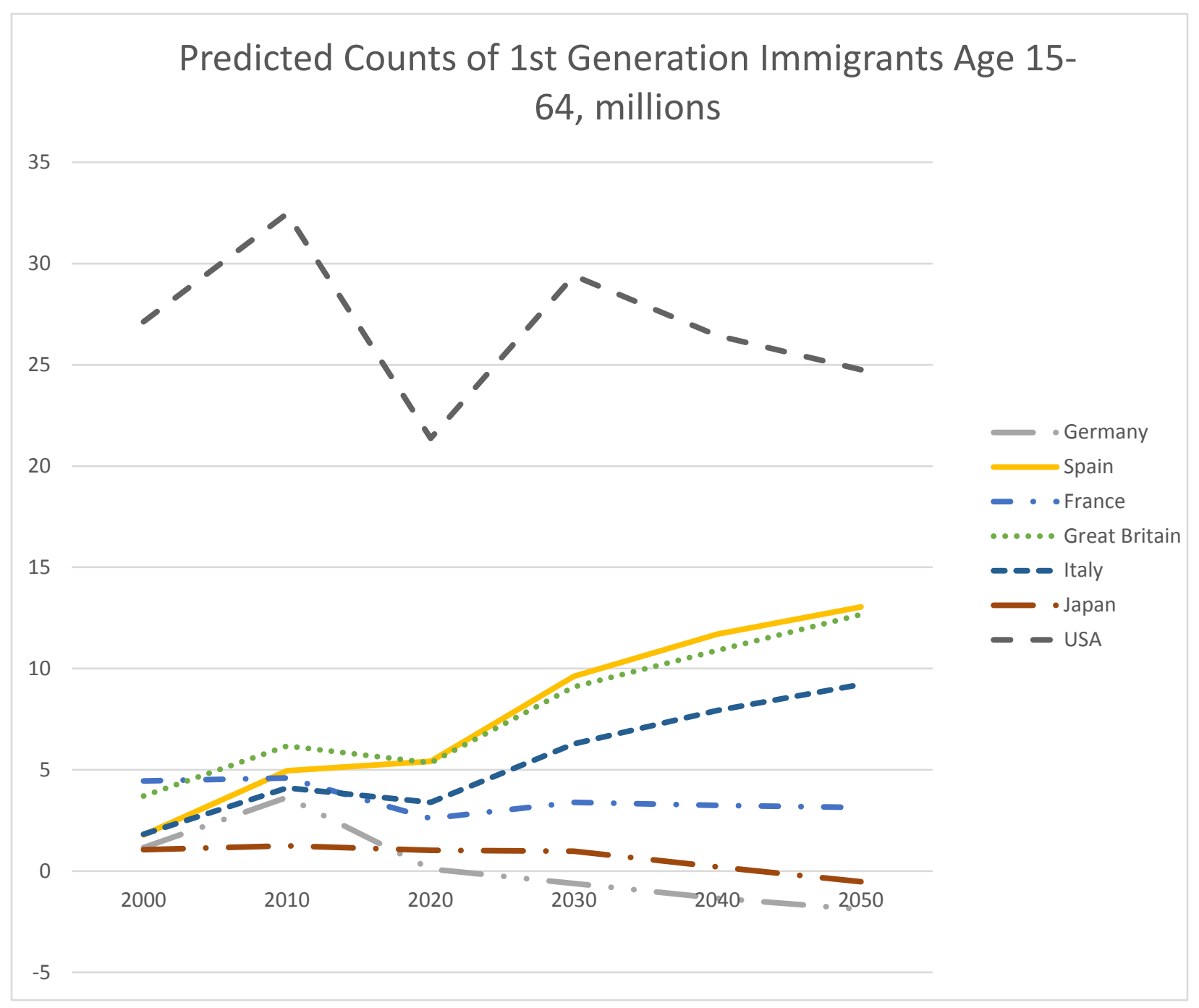




\section{Figure 4. Migration Projections by Origin and Destination}
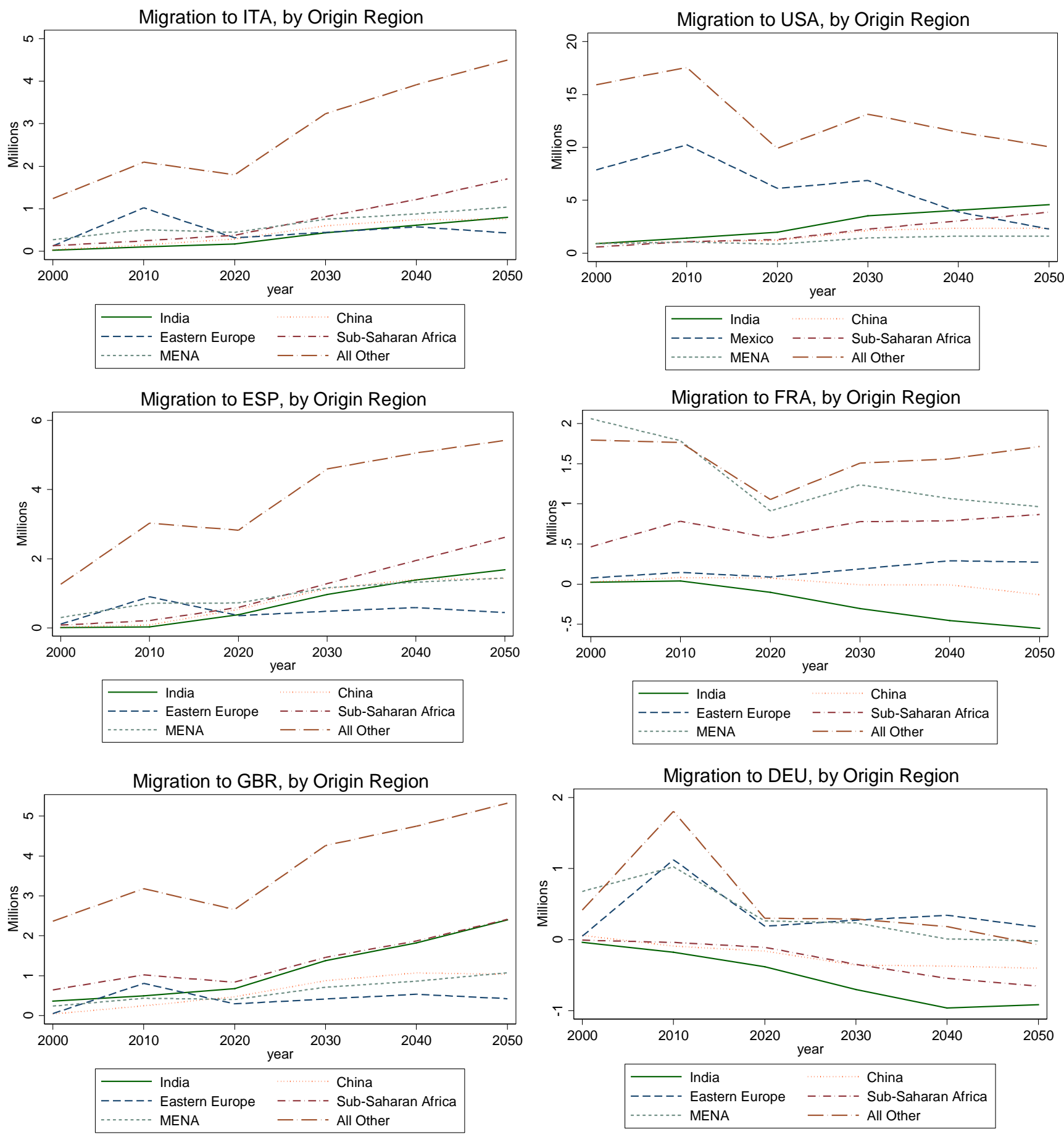


\section{Online Appendix}

\section{A1. Estimation of the forecasting model.}

We estimate the forecasting model using 2000-2010 migration flows, as in Table 2, except that now we include all seven of the dyad-level gravity variables simultaneously in a single regression. The variables used in the analysis are: $y_{c s d, t}$, the percentage of age-gender group $c$ from sending-country $s$ that has migrated to destination-country $d$ as of year $t ; \frac{L_{c s, t}}{L_{c d, t}}$, the relative size of age cohort $c$ for sending-country $s$ and destination-country $d$ at time $t ; \frac{w_{c s, t}}{w_{c d, t}}$, relative per capita GDP for age cohort $c$ corresponding to dyad $s d$ at time $t$; and $\delta_{c}$, $\delta_{s}$, and $\delta_{d}$, fixed effects for the cohort, sending country, and destination country.

The estimating equation is,

$$
\begin{aligned}
y_{c s d, t+1}-y_{c s d, t} & \\
& =\delta_{c}+\delta_{s}+\delta_{d}+\alpha\left[\ln \frac{L_{c s, t}}{L_{c d, t}}-\ln \frac{L_{c s, t-1}}{L_{c d, t-1}}\right]+\beta_{1}\left[\ln \frac{w_{c s, t}}{w_{c d, t}}\right]+\beta_{2}\left[\ln \frac{w_{c s, t}}{w_{c d, t}}\right]^{2} \\
& +\sum_{i} \gamma^{i} \tau_{s d}^{i}+\sum_{i} \rho^{i}\left(\left[\ln \frac{L_{c s, t}}{L_{c d, t}}-\ln \frac{L_{c s, t-1}}{L_{c d, t-1}}\right] * \tau_{s d}^{i}\right)+\varepsilon_{c s d}
\end{aligned}
$$

where the gravity variables $\tau_{s d}^{i} i=1, \ldots, 7$, are log distance between the sending and destination country, indicators for the sending and destination country having a common border, common language, and shared colonial history, and indicators for whether the migration rate of overage-50 migrants from the sending to the destination country in 2000 was in the top 50 percent, top 20 percent, and top 5 percent across all sending-destination dyads.

Using our labor-supply projections derived from UN data and GDP forecasts derived from IMF data (as described in the text), we predict the dyadic decadal migration flows that will occur for the four 10-year age cohorts (15-24, 25-34, 35-44, and 45-54) over four decades (2010-2020, 20202030, 2030-2040, and 2040-2050). The labor-supply values that we feed into the forecasts include a mix of cohorts already born and cohorts yet to be born, as of 2015. The oldest already-born cohort is aged 45-54 in 2010 and thus is used in the forecast only once for the change in migration rate over 2010-2020; the youngest already-born cohort is aged 5-14 in 2010 and which is used to forecast migration flows over 2020-2030, 2030-2040, and 2040-2050; and the youngest yet-to-be born cohort is aged 15-24 in 2040 and used to forecast migration flows over 2040-2050. Of the 7 birth cohorts represented in the analysis, two are born after 2015; of the 16 age cohorts used in the forecasts ( 2 birth cohorts appear in the analysis once, 2 appear 2 times, 2 appear 3 times and 1 appears 4 times), 3 correspond to individuals born after 2015. See note 13 in the main text for a listing of each birth cohort and how many times it appears in the data. 
To construct forecasts of migrant stocks, we add these forecasted decadal migration inflows to any pre-existing migrant stocks and proceed to calculate future stocks of migrants from each origin in each destination in each decade. Where we observe stocks of migrants at the beginning of the period, we add the forecasted flows to these stocks. Where we predict flows for new cohorts with no observed migration, we assume that the initial stock of migrants is zero. These predicted stocks can then be summed across gender, age, origin, or destination to calculate totals of foreign-born migrants aged 15-64 for each decade. With zero predicted future migration flows, or predicted decadal flows after 2010 that are smaller than average decadal flows before 2010, forecasted migrant stocks in destination countries decline over time, as larger cohorts of older migrants age out of the 15-64 age group and smaller cohorts of new migrants are incorporated into the stock. With predicted decadal flows after 2010 that are larger than average decadal flows before 2010, forecasted migrant stocks rise over time. 


\section{Appendix Table A1: Regression used to fit the prediction model.}

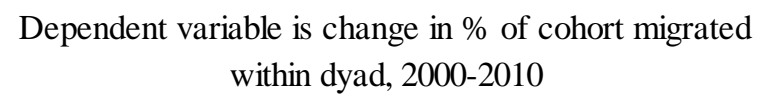

Constant
Coefficient (Standard Error)

$0.295^{* *}$

0.00272

(0.006)

$0.00265^{* * *}$

$(0.001)$

$0.0111^{* *}$

(0.006)

$-0.0389 * * *$

(0.014)

0.0111

(0.012)

$0.121^{* * *}$

$0.159 *$

(0.096)

$0.675 * * *$

$-0.0213^{* * *}$

$-0.0381^{* *}$

(0.015)

0.0972

(0.079)

$0.917^{* *}$

$-0.0504 * *$

$-0.178^{* *}$

(0.077)

$0.0622^{* * *}$

(0.008)

0.0547

(0.035)

$0.555 *$

(0.310)

18,297

$\begin{array}{lr}\text { Observations } & 18,297 \\ \text { R-squared } & 0.114\end{array}$

Analysis includes fixed effects for 10-year birth cohorts, origin, destination, and gender. Weighted by birth cohort population size to make results representative for all individuals born in the origin countries. Standard errors clustered at the dyad/gender/cohort level. ${ }^{* * *} \mathrm{p}<0.01,{ }^{* *} \mathrm{p}<0.05,{ }^{*} \mathrm{p}<0.1$. 


\section{A2. Varying GDP growth in the forecasts.}

We are almost certainly able to forecast population more accurately than GDP. This raises the question of the sensitivity of our forecasts to potential future swings in GDP. For example, imagine that Africa were to enter a high-growth period, how much would the resulting increase in labor demand hold back pressures for emigration that our model otherwise suggests will take place? To answer this question, we feed alternate scenarios for GDP growth into our prediction model, examining outcomes if African GDP grew $10 \%, 25 \%$, and $50 \%$ faster than the IMF forecast currently predicts.

Examination of Table A1 already suggests that the effect may be modest, but positive; meaning that higher income ratios would encourage higher emigration. The coefficients on GDP ratios are small, and indicate a convex relationship meaning that the effect will be smallest for countries such as those in SSA who would begin a change in income ratios from a low base.

Indeed, when we examine the migration predictions produced by the different GDP runs, we find a trivially small difference between them. Table A2 shows that while we do get a noticeable difference in prediction values when we move from a model without GDP to one with the linear and quadratic function of the GDP ratios, varying the economic growth rate of countries in SubSaharan Africa by wide margins has little effect on migration rates. This is largely because GDP ratios have only a very weakly positive relationship with migration when the income gap between origin and destination is large.

\section{Appendix Table A2: Predicted Migration when Shifting GDP Forecasts.}

Correlation between forecasts of migrant stocks for SSA from $2020 \mathrm{on}$ :

\begin{tabular}{|c|c|c|c|c|c|}
\hline & No GDP & $\begin{array}{c}\text { GDP ratio linear } \\
\text { \& quadratic }\end{array}$ & $\begin{array}{c}\text { African GDP up } \\
\text { by 10\% }\end{array}$ & $\begin{array}{c}\text { African GDP up } \\
\text { by 25\% }\end{array}$ & $\begin{array}{c}\text { African GDP up } \\
\text { by 50\% }\end{array}$ \\
\hline No GDP & 1 & & & & \\
\hline $\begin{array}{c}\text { GDP ratio line ar \& } \\
\text { quadratic }\end{array}$ & 0.9741 & 1 & 1 & & \\
\hline $\begin{array}{c}\text { African GDP up by } \\
10 \%\end{array}$ & 0.9735 & 1 & 1 & 1 & \\
\hline $\begin{array}{c}\text { African GDP up by } \\
\text { 25\% }\end{array}$ & 0.9726 & 0.9999 & 0.9998 & 0.9999 & 1 \\
\hline $\begin{array}{c}\text { African GDP up by } \\
50 \%\end{array}$ & 0.9713 & 0.9997 & 0 & \\
\hline
\end{tabular}

Note: 'GDP ratio linear \& quadratic' is the specification used in the paper's main tables. 